\title{
Article
}

\section{Stem Cells and Society: An Undergraduate Course Exploring the Intersections among Science, Religion, and Law}

\section{Chris Pierret and Patricia Friedrichsen}

\author{
University of Missouri, Columbia, MO 65211 \\ Submitted September 10, 2008; Revised November 10, 2008; Accepted November 18, 2008 \\ Monitoring Editor: Robin Wright
}

\begin{abstract}
The intersection of science and our society has led to legal and ethical issues in which we all play a part. To support development of scientific literacy, college science courses need to engage students in difficult dialogues around ethical issues. We describe a new course, Stem Cells and Society, in which students explore the basic biology of stem cell research and the controversy surrounding it. As part of the course, we highlight the nature of science, looking at the methods and norms within the scientific community. To gain a perspective on the current stem cell controversy, we examine the public debates in the 1970s surrounding in vitro fertilization, the stem cell initiative in Missouri, and the personal and religious viewpoints that have emerged relative to the stem cell debate. In the Stem Cells and Society course, students are challenged to develop and clarify their own personal positions concerning embryonic stem cell research. These positions are grounded in science, religion or personal philosophy, and law.
\end{abstract}

\section{INTRODUCTION}

\begin{abstract}
"The tremendous advances in pure science made during the 20th century have completely changed the relation between science and society. Through its technological applications, science has become a dominant element in our lives. It has enormously improved the quality of life. It has also created great perils, threatening the very existence of the human species. Scientists can no longer claim that their work has nothing to do with the welfare of the individual or with state policies." (Rotblat, 1999).
\end{abstract}

In response to rapid advances in science, reports from prestigious scientific societies, including Science for All Americans, Benchmarks for Scientific Literacy, and the National Science Education Standards, call for scientific literacy as the central goal of science education (American Association for the Advancement of Science [AAAS], 1989, 2003; National Research Council [NRC], 1996). Scientific literacy has been defined as "the knowledge and understanding of science concepts and processes required for personal decision making, participation in civic and cultural affairs, and economic productivity" (NRC, 1996). Unfortunately, in the

DOI: $10.1187 /$ cbe.08-09-0053

Address correspondence to: Chris Pierret (pierret.christopher@ mayo.edu).
United States, the goal of scientific literacy has yet to be realized (Gross et al., 2005; Moore, 2006).

In Missouri, the need for a scientifically literate citizenry came into sharp focus during a recent statewide vote on a controversial stem cell initiative (SOS-MO, 2005). To cast an informed vote, citizens needed to understand the basic science of somatic cell nuclear transfer (SCNT) and be able to interpret the initiative's definition of human cloning. The issues, however, ran much deeper than understanding basic science. Statewide, citizens debated moral and ethical issues surrounding embryonic stem cell research. Personal philosophies and religious perspectives played prominent roles as citizens weighed the positive and negative implications of embryonic stem cell research on society.

During this time, we were designing a new undergraduate stem cell course for nonscience majors. Initially, we planned to focus on the basic science of embryonic stem cells and confront commonly held misconceptions related to stem cells. The statewide debate on embryonic stem cell research caused us to reconsider what it means to be scientifically literate. Zeidler et al. (2005) advocated the need for a broader conceptualization of scientific literacy to include: "informed decision making; the ability to analyze, synthesize, and evaluate information; dealing sensibly with moral reasoning and ethical issues; and understanding connections inherent among socioscientific issues (SSI)." Socioscientific issues are described as "social dilemmas with conceptual ties to science (Sadler et al., 2004). 
We decided to shift the focus of the course to helping students develop and articulate their own positions on embryonic stem cell research. We were unsure of how we would handle potential conflicts between students with opposing viewpoints, so we turned to a faculty development program on our campus, Difficult Dialogues. This program focuses on "teaching and reinforcing dialogue skills and religious literacy that encourage difficult dialogues on important, challenging topics and are essential to democratic citizenship in an increasingly diverse society" (Difficult Dialogues, 2007).

We used the lessons of Difficult Dialogues to revisit our course goals and found that we needed to make room for more exploration of religious, philosophical, and legal aspects of stem cell research. Specifically, we incorporated facilitated discussions, guest lectures by religious and legal experts, readings in the humanities, and a commitment to creating a safe classroom environment for sharing diverse views on stem cell research.

\section{OVERVIEW}

We taught the Stem Cells and Society course in May 2007 as part of our university's 3-wk intersession (between the spring and summer semesters). The 1-credit course met for $2.5 \mathrm{~h}$ three times a week, for a total of eight class sessions. The only prerequisite for the course was the successful completion of an introductory biology course. The 15 students who enrolled in the course represented a wide range of students, including biology majors and nonscience majors, second year students through seniors (Table 1). Required course materials included: Stem Cell Now (Scott, 2006) and Being Human: Core Readings in the Humanities (Kass, 2004).

\section{COURSE GOALS}

Stem Cells and Society was developed around three central learning goals: 1) to develop, clarify, and communicate a personal position on human embryonic stem cell research; 2) demonstrate an understanding of the characteristics of stem cells, their microenvironment, and their therapeutic potential; and 3) to develop an understanding of science as a human endeavor and the interactions between science and society, with a focus on religion and law related to stem cell research.

To help students meet the first goal, we focused on the central question, "When do human rights begin?" As we presented an overview of human development from fertilization through birth, students were asked to identify the point in time in which they believe human rights begin. To answer this question, students needed to clarify their own religious or personal philosophies. Through class discussions, students became aware of different perspectives within the group, and began to see the complexity of the controversy surrounding human embryonic stem cell research. We wanted to avoid the tendency for discussions to be reduced to simple prolife versus prochoice arguments that fail to encompass the breadth of positions concerning stem cell research. To avoid this tendency, we needed to develop classroom norms that created a safe environment for students to share their thoughts. To help students think more deeply about this issue, we also wanted to identify, and resolve when possible, instances of dissonance within students' positions on human rights. For instance, is it possible to be prochoice and anti-human embryonic stem cell research? Or can one resolve support for stem cell research while believing in "life at conception"?

The second course goal focused on understanding the basic science concepts related to embryonic stem cell re-

Table 1. Student demographics

\begin{tabular}{|c|c|c|c|c|}
\hline \multicolumn{5}{|c|}{ A: Student demographic data } \\
\hline Student & Gender & Biology major? & Year & Onset of human rights \\
\hline A & Female & Yes & Sophomore & Birth \\
\hline B & Male & Yes & Senior & Fertilization \\
\hline $\mathrm{C}$ & Female & Yes & Junior & Brain activity \\
\hline $\mathrm{D}$ & Female & Yes & Junior & Implantation of embryo \\
\hline $\mathrm{E}$ & Female & Yes & Senior & Fertilization \\
\hline $\mathrm{F}$ & Female & Yes & Junior & Fertilization \\
\hline G & Female & Yes & Sophomore & Birth \\
\hline $\mathrm{H}$ & Male & No & Junior & Brain activity \\
\hline I & Male & No & Senior & Heartbeat \\
\hline $\mathrm{J}$ & Female & No & Sophomore & Fertilization \\
\hline K & Female & No & Sophomore & Fertilization \\
\hline $\mathrm{L}$ & Female & No & Senior & Birth \\
\hline M & Female & No & Sophomore & 4 mo after fertilization \\
\hline $\mathrm{N}$ & Male & No & Senior & Birth \\
\hline $\mathrm{O}$ & Female & No & Senior & Birth \\
\hline
\end{tabular}

B: Categorical comparison

Male: female ratio

Fertilization: other: birth ratio 
Table 2. Course goals

Course

1. Develop and clarify a personal position on human embryonic stem cell research.

2. Demonstrate understanding of the characteristics of stem cells, their microenvironment, and their therapeutic potential.

3. Develop an understanding of science as a human endeavor and the interactions between science and society, with a focus on religion and law related to stem cell research.
Objectives

1. Become aware of the range of philosophies concerning stem cells within our community.

2. Articulate your philosophy in written and spoken word.

3. Develop the necessary skills to share an open discourse with those who hold views that directly oppose your own.

4. Use an ethical decision-making model to hone personal position on current uses of stem cells.

1. Demonstrate understanding of cell cycle by identifying phases of the cell cycle.

2. Describe embryonic and fetal development by identifying the characteristics of blastocyst, gastrulation, germ layer.

3. Identify and discuss roles of stem cells, transit amplifying cells, precursors, and postmitotic cells within the stem cell niche.

4. Differentiate between embryonic stem cells and adult stem cells, identifying the differences in plasticity, source, and role of embryonic stem cells and adult stem cells.

5. Understand and describe SCNT.

6. Describe current therapeutic advances in Alzheimer's, Parkinson's, Diabetes, and Spinal Cord Injuries.

1. Outline legislative approaches to describe and control stem cell research within the United States and internationally.

a. Compare and contrast the U.S. state legislative initiatives discussed in class.

b. Discuss Missouri Amendment 2 and the controversies of its passage.

2. Compare the emergence of in vitro fertilization with the current introduction of stem cell therapy.

3. Discuss the breadth of positions on embryonic stem cell research taken by religions represented in our community.

4. Explore the questions "Who is a scientist?" and "How is science done?" search. Both in popular media and scientific journals, there has been an inconsistent use of terminology related to stem cell research. Rather than focus on confusing terminology, we focused on the basic science concepts needed to understand stem cell research. To introduce stem cells, we returned to our overview of human development. By reviewing this process, we could discuss similarities and differences between embryonic stem cells and those popularly identified as adult stem cells. As the working model for uniform identification and functional understanding of stem cells, we focused on the stem cell niche, the cells and microenvironment in which they are found. In addition, we wanted to explore the promise of stem cells, both in peerreviewed journals and in the popular press. To accomplish this objective, we described the most current research on the therapeutic potential of various stem cell types using the basic developmental biology to which they had been introduced.

Our final goal was to examine the intersections among science, religion, and the law as related to embryonic stem cell research. First, we wanted students to gain a historical perspective of legislation related to basic human rights. Next, we wanted students to become familiar with state and federal laws, as well as international policies. Also, we introduced students to aspects of the nature of science, focusing on science as a human endeavor and the interactions of science and society (NRC, 1996). We wanted students to see scientists as people who are "influenced by societal, cultural, and personal beliefs and ways of viewing the world" (NRC, 1996). Based on these three goals and their underlying objectives (Table 2), we developed six major class activities. In the next section, we describe each of these activities and give examples of student work. Assessment tools, both formative and summative, are included in Table 3.

\section{MAJOR COURSE ACTIVITIES}

\section{Test Tube Babies}

In the first in-class activity, we viewed the PBS program, "Test Tube Babies" (PBS Home Video, 2006) to introduce an 
Table 3. Class schedule/overview

\begin{tabular}{|c|c|c|c|}
\hline Day & Activities & Formative assessments & Summative assessments \\
\hline 1 & $\begin{array}{l}\text { - Welcome/class overview } \\
\text { - Student introductions } \\
\text { - Notecards: Developmental milestones } \\
\text { - Pair/share: Human rights } \\
\text { - Introduction to scientific literacy } \\
\text { - Invitation to participate in research } \\
\text { - Science concept pretest } \\
\text { - Video: Early development } \\
\text { - Reaction writing: Any changes to } \\
\text { earlier milestones } \\
\text { - Lecture: In vitro introduction }\end{array}$ & $\begin{array}{l}\text { - Notecard: Developmental milestones = human } \\
\text { rights } \\
\text { - Journal writing: Any changes after learning more } \\
\text { about development? } \\
\text { - Student introductions } \\
\text { - Concept pretest }\end{array}$ & \\
\hline 2 & $\begin{array}{l}\text { Welcome/review } \\
\text { - Introduce journal rubric } \\
\text { - Introduce persona position paper } \\
\text { - Development (cont.) and stem cell } \\
\text { concepts } \\
\text { - PBS video }\end{array}$ & $\begin{array}{l}\text { - Small group participation } \\
\text { - Individual journal writing: Describe a human being } \\
\text { - Small group note card: Human being } \\
\text { - Small group startup, determine personas for project }\end{array}$ & \\
\hline 3 & $\begin{array}{l}\text { - Welcome } \\
\text { "Faith Takes": Students present } \\
\text { PBS video (cont.) } \\
\text { - Small group: React to video, describe } \\
\text { the players } \\
\text { - Student evaluation of teaching } \\
\text { methods thus far }\end{array}$ & $\begin{array}{l}\text { - QA to Faith Takes } \\
\text { - Visit with small groups. } \\
\text { - Notecard: Evaluation of methods and books }\end{array}$ & · Faith Takes \\
\hline 4 & $\begin{array}{l}\text { Welcome } \\
\text { - Lecture: Stem cells, SCNT, niche (and } \\
\text { analogies) } \\
\text { - Small group: plan persona paper }\end{array}$ & $\begin{array}{l}\text { - Journal content } \\
\text { - QA lecture } \\
\text { - Small group niche analogies }\end{array}$ & - Journal completion first viewing \\
\hline 5 & $\begin{array}{l}\text { - Niche review / follow-up on analogies } \\
\text { - Journal writing: React to assigned } \\
\text { readings concerning Hwang and } \\
\text { scientific ethics } \\
\text { - Small group: What/who is a scientist } \\
\text { - Lecture: the promise of stem cells }\end{array}$ & $\begin{array}{l}\text { - Small group notecard: Describe a scientist from } \\
\text { point of view of our } 2 \text { texts, the NY Times assigned } \\
\text { readings, and the PBS video }\end{array}$ & - Persona position paper \\
\hline 6 & $\begin{array}{l}\text { - Welcome } \\
\text { - Guncept posttest } \\
\text { Religious Studies; Religious } \\
\text { Dissonance and Just War } \\
\text { - Large group discussion: with Sharon } \\
\text { - Introduce models of decision making }\end{array}$ & - QA with guest speaker & - Concept posttest \\
\hline 7 & $\begin{array}{l}\text { Welcome } \\
\text { - Review of journal rubric } \\
\text { "Nation-States": State, federal laws on } \\
\text { stem cells, and MO amendment } 2 \\
\text { Small group preparation for guest } \\
\text { speaker } \\
\text { - Guest Lecture: Philip Peters, Jr. from } \\
\text { MU Law School; Legal Dissonance } \\
\text { - Small group preparation for town hall } \\
\text { meeting "Norms for safe discussions" }\end{array}$ & $\begin{array}{l}\text { QA lecture and with guest speaker } \\
\text { - Small group notecard: Questions for guest speaker } \\
\text { - Group preparation of norms: Ground rules for our } \\
\text { forum on Day } 8\end{array}$ & \\
\hline 8 & $\begin{array}{l}\text { Welcome } \\
\text { - Introduction of community } \\
\text { participants } \\
\text { - Final forum } \\
\text { - Class evaluations }\end{array}$ & & $\begin{array}{l}\text { Forum participation/discussion } \\
\text { overview } \\
\text { - Journal } \\
\text { - Position paper }\end{array}$ \\
\hline
\end{tabular}

historical example of a socioscientific issue. This PBS program provides excellent information on the science of in vitro fertilization, while presenting multiple perspectives on the use of this technology. In class discussions, students compared and contrasted societal reaction to in vitro fertilization to contemporary societal reactions to stem cell research. Individually, students wrote journal responses reacting to the human rights issues highlighted in the film. We 
used this first activity to develop a safe classroom environment that supported the discussion of controversial issues. By introducing a socioscientific issue from the 1960s and 1970s, we thought that students would feel safer discussing this issue than if we immediately jumped into a discussion of human embryonic stem cell research. Many of the basic scientific concept objectives were addressed through use of the supporting website materials, and also through class discussions. The film's depiction of the medical doctors and researchers involved in the first attempts of in vitro fertilization was an excellent introduction to our third goal. The doctors and scientists in the film were portrayed as real people with pressures from institutional policy and federal law. In addition to journal writing and group discussion, we asked students, before and after viewing the film, to identify adjectives that they felt best described scientists.

\section{Faith Takes}

To help students develop their own personal position on embryonic stem cell research, we designed a two-part activity, "Faith Takes." First, students were asked to take an objective stance and explore abortion, embryonic stem cell research, and euthanasia from two different religious viewpoints. For example, one group compared and contrasted Hindu and Jewish perspectives on these issues. In small groups, students explored their selected religious stances, and prepared an in-class presentation to share this information. As instructors, we generated a list of religions that students might explore and encouraged students to present their own viewpoint and a religious viewpoint different from their own. Each small group presentation was followed by a question and answer session. For the second part of the activity, we invited a Religious Studies Department faculty member to speak with our class. The speaker led a discussion that examined many world religions and philosophies and led to a very interesting discussion of "Just War Theory," which explored the justifications for why and how wars are fought. The intention of this two-part activity was to validate a wide range of religious viewpoints. By presenting and discussing a broad array of perspectives, students began the process of identifying with a given position, and began to identify examples of dissonance within their own and others' positions.

\section{Niche Analogies}

To address our second course goal related to the basic science of stem cell research, we used analogies to help students construct an understanding of the stem cell niche. Analogies have been shown to help students develop deeper conceptual understanding (Glynn and Takahashi, 1998). We introduced the stem cell niche by using the analogy of make-believe character, Walter, hiding in a mound of rocks (Figure 1; Martin, 1995). In this analogy, we introduced Walter as the stem cell and assigned components of his dwelling to those described in a stem cell niche. Next, students worked in small groups to create their own unique analogy for a stem cell niche, which included stem cells, transit-amplifying cells, helper cells, microenvironmental cues, and a basal lamina. Later, on the final exam, students were asked to create a second unique analogy to demon-

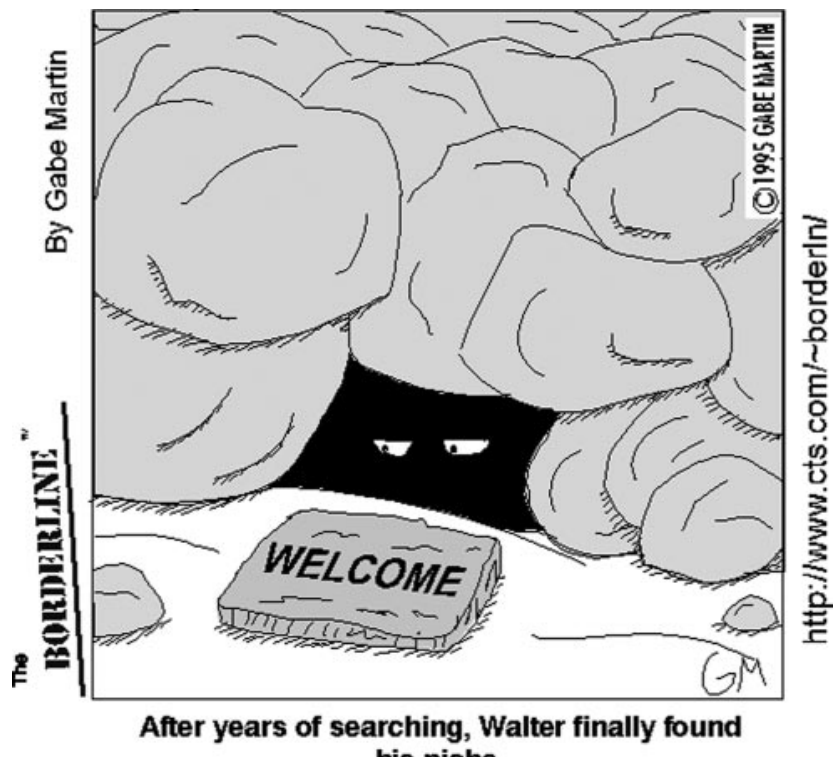

his niche.

Figure 1. Gabe Martin cartoon depicting Walter in his niche. This cartoon was used to help students understand the goals of the Niche Analogy activities. This cartoon is used by permission from Borderline Press.

strate their understanding of the components of a stem cell niche. Student analogies included hockey rinks, cruise ships, and even beauty salons, all of which demonstrated an understanding of niche components. This activity was intended to support students in developing an understanding of the basic science of stem cell research. There are basic needs and activities that define the nature of stem cells. Once those needs and activities are understood, we feel that the promise of stem cell therapies is easier to describe.

\section{Persona Positions}

The "Persona Positions" activity was designed to support students in meeting all three course goals. For this activity, students worked in small groups. Each small group was asked to take on the persona of a specific group of people and express that group's viewpoint on human embryonic stem cell research. Students could select from the following groups: U.S. senators, science researchers, prolife activists, or terminally ill patients. We asked students to select a persona representing a viewpoint different from their own. By having students identify with an opposing viewpoint, we felt that it would be easier for students to explore the basis for the persona's viewpoint. As part of the activity, students were required to identify the persona's position on when human rights begin, the basis for this position, and whether current state and federal laws supported this position. As a follow-up to this activity, students wrote individual position papers in a similar format, but expressing their own personal viewpoint.

\section{Nation-States}

In this activity, we examined laws regulating embryonic stem cell research. We began with reading Missouri's Amendment 2 and comparing this law to other states' legislation (Secretary of 
State Robin Carnahan, Missouri [SOS-MO], 2005). After comparing state laws, we examined the U.S. federal policy regarding embryonic stem cell research and compared U.S. federal policy to key countries around the world, selecting countries that represented a range of positions. After exploring state and federal law, we invited a professor from our university's Law School to speak with our class. The speaker highlighted inconsistencies within law related to human rights. For instance, we define human rights in different manners in relation to abortion, euthanasia, capital punishment, and stem cell research. The law professor also described the power of prolife and prochoice groups in our state in regard to impending legislation relating to human life and rights issues.

\section{Final Forum}

The culminating activity of the course was a facilitated community discussion, "Final Forum." For this class activity, we worked with our university's Center on Religion and the Professions to invite community members representing Buddhism, Hinduism, Daoism, Judaism, Islam, Catholicism, and liberal and fundamental Christianity to participate in an open discussion of their views on human embryonic stem cell research. By working with our community volunteers beforehand to ensure they understood the nature of the Final Forum, we were able to maintain a comfortable environment for both guests and students. We were not looking for experts, only individuals who had an opinion about stem cell research that was grounded in a faith or personal philosophy. Community members shared personal experiences and philosophy-based statements on their view of the onset of human rights. Participation in the Final Forum allowed students to demonstrate their success in all three goals.

Before the discussion, students worked together to set ground rules for the discussion that they felt would best create an atmosphere supportive of open discussion. To begin the discussion, students and community members formed small discussion groups and shared viewpoints. The small group discussions were followed by a whole class discussion. The goal of the discussion was simple: find and appreciate the diversity of positions on embryonic stem cell research that can be found in our community. This activity also addressed the science concept goal and nature of science goal, as students were expected to express their opinion with a scientific basis and a growing understanding of how science is conducted.

\section{ADDITIONAL INSTRUCTIONAL STRATEGIES}

In this section, we describe additional instructional strategies we used to support the major course activities, which included: in-class free-writes, nightly journaling, readings in the humanities, readings related to the science of embryonic stem cells, an online discussion forum, and pair and share activities. Free-writing and journaling were included to allow students to organize their thoughts before discussions as well as to decompress emotions that surfaced during a given activity. Also, by reflecting on their reactions to all classroom activities, students were better prepared to participate in the Final Forum. Between each class session, we assigned related readings in the humanities and in developmental biology. These readings were assigned to help students develop an understanding of how society views and shapes science. One follow-up task included describing a scientist from the viewpoint of each of our assigned texts. We used an online discussion forum to give students the opportunity to continue class discussions. We wanted to provide opportunities for students to express their viewpoints, even if time ran short in class. The online forum was maintained several weeks after the last class session. In all activities we started interactions on a small scale and allowed them to expand. We felt that this strategy would establish a safe classroom environment for thoughtful class discussions. For this reason, we would generally begin with a presentation, move to "pair and share" with a partner, then advance to small group and eventually large group discussions. Given the short, 3-wk time frame, we felt that this would be the best method of achieving the trust necessary to share thoughts and feelings on controversial issues.

\section{ASSESSMENT}

Table 2 describes the strategies used to assess progress toward our course goals and objectives. Additional information on class activities and associated assessments can be found in Table 3. In response to our first goal, class activities were designed to increase students' comfort with sharing their opinions with their classmates. Students first worked on individual free-writing assignments, then worked with a partner to discuss their thoughts. As the course progressed, we moved to small group discussions, large group discussions, then a final community discussion group. The final assessment of this goal was a personal position paper that required students to synthesize and reflect on their experiences in the course. In this assignment, we prompted students to explore philosophy, religion, science, and the law. Students were provided a decision-making worksheet (Bivins, 2000) that blended philosophy with ethics to help clarify their position. Two excerpts demonstrating a small subset of the variety of views represented in our class can be found in the Supplementary Material (Supplementary Text 1). We were fortunate to have a wide range of positions represented in our class, forming a broad continuum of personal philosophies.

To demonstrate scientific literacy in the area of stem cell research, students should be able to understand the basic developmental biology of stem cells. Assessment of this goal was determined by a pre- and posttest. The posttest score was included as part of the course grading, representing 60 of 200 total points, with both tests containing a bonus question that was worth 5 additional extra credit points. Pretest scores ranged from 7 to 28 of 60 points, with an average of 17.2 points (28.6\%). Posttest scores ranged from 35 to 65 of 60 points (with extra credit available), with an average score of 50.8 points $(84.6 \%)$. Average individual improvement was 32.1 points.

Assessment of students' understanding of the interactions between science and society occurred with the activities of the Faith Takes strategy. Student presentations included not only an exploration of previously unfamiliar religions, but also an explanation of the political and legislative viewpoints brought about by the official positions of those reli- 
gions with regard to stem cell research. Nation-States also gave way to small and large group discussions that revealed religion's influence on legislation and its impact on our society. The most complete summative assessment of the third goal was evaluated using the rubric for the personal position paper assignment. The syllabus, test, rubrics, and assignment sheets are included in the Supplementary Material.

\section{STUDENT EVALUATIONS OF TEACHING STRATEGIES}

We used a number of data sources to evaluate the effectiveness of each of the teaching strategies. First, the students' journals were a data source as the students evaluated several of the strategies in their journals, including Test Tube Babies, Faith Takes, Persona Positions, and Nation-States. The use of niche analogies was not evaluated in the student journals, so this strategy was evaluated by examining two sets of student work: analogies created in small groups and the final analogies that students produced for the science concept examination. An additional evaluation of analogies was found in one student journal. The Final Forum was evaluated on the student course evaluations. Two of the strategies included related assignments: the small group Persona Position papers and in-class presentations for Faith Takes. We also examined students' written responses to in-class questions related to these two strategies. Additional data were available from the university course evaluations from the students.

We designed a continuum to quantify the effectiveness of each teaching strategy, as shown in Table 3. To quantify the student-generated text-based data, we used the following method of analysis. First, we read all the student data related to a specific teaching strategy several times, looking for language that revealed students' perceptions of the effectiveness of a particular teaching strategy. For each strategy, student assessments were then placed in order from those that contained language that rated the strategy most effective to those that rated the strategy least effective. Language that further separated the evaluations was identified and a value ascribed to each break. Using these assigned values, an average was determined for each teaching strategy. Additionally, student comments from assignments, note cards, and course evaluations are included within the Supplementary Material to represent student comments of that particular value (Supplementary Text 2). Continuum values for several of the strategies are shown in Table 4.

\section{Test Tube Babies}

This strategy was scored by the students to be "somewhat effective" in meeting Goal 3. After showing the film, we prompted students to journal in response to the question, "Why did we include this film in a course about stem cells?" Below is a response from a student who understood our instructional objective:

\footnotetext{
"It was unique that they brought this to court, so it was covered by news nation/world wide. As the video stated, it forced people to get an opinion on the matter. The birth of Louise Brown allowed those who were concerned about IVF to see its fullest success. A
}

Table 4. Student evaluations of teaching strategies

A: Teaching strategy efficacy rating continuum

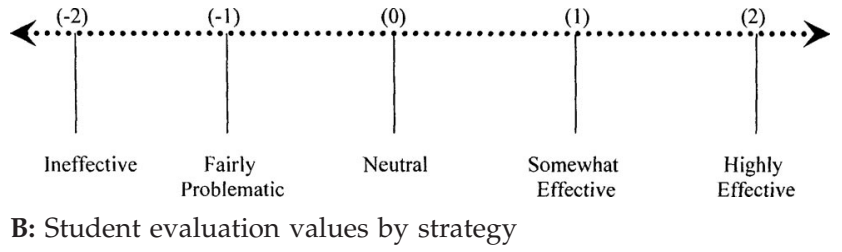

\begin{tabular}{lcccc}
\hline Student & Test Tube & Faith Takes & Persona & Nation-States \\
\hline 1 & 2 & 2 & 1 & 2 \\
2 & -1 & 1 & 1 & 1 \\
3 & 2 & 2 & -2 & 0 \\
4 & 2 & 1 & 1 & 2 \\
5 & 2 & 1 & -2 & 2 \\
6 & 2 & 2 & 0 & 2 \\
7 & 2 & 2 & 1 & 0 \\
8 & 2 & 2 & 0 & 1 \\
9 & 2 & 1 & 1 & 1 \\
10 & $\mathrm{NA}$ & 2 & 1 & 2 \\
11 & 2 & $\mathrm{NA}$ & 1 & 1 \\
12 & -1 & 1 & -1 & 1.3 \\
Average & 1.3 & 1.5 & 0.1 & $\mathrm{~N}$ \\
\hline
\end{tabular}

\begin{abstract}
societal implication for Louise [included] the jokes that were made by those in media or who opposed IVF strongly. The first IVF clinic to open faced many challenges from antiabortion groups. Because only 2 more successes were given in 10 years, it was shown that the science of IVF was very new. I think the beginning of IVF research is pretty similar to stem cell research today. Although stem cells are more complex, the basic science of unknowns toward the beginning is similar." (Student 1)
\end{abstract}

Overall, in nine of 11 responses, students gave this strategy their highest rating. The clash between segments of society and those wishing to pursue IVF several decades ago parallels current tensions surrounding embryonic stem cell research. Though the ethical dilemma at hand is equivalent, over time IVF has become a more approachable subject for students, and, therefore, a more comfortable topic for group discussion.

\section{Faith Takes}

Students rated this strategy as "highly effective" in meeting Goal 3. Student journal entries following the Faith Takes activities were volatile:

\begin{abstract}
"I choose not to believe in a deity because I privilege reason over faith - I see no reason in faith in a God of some sort. I also think it is fairly ridiculous to base law or scientific decisions on faith or some ancient, translated, and retranslated text. I found in my group that there are people that are opposed to stem cell research strictly because of their positions as Christians. To me, this is unreasonable." (Student 4)
\end{abstract}

This strategy was likely made most effective by the quality of our outside expert's presentation. It was necessary to 


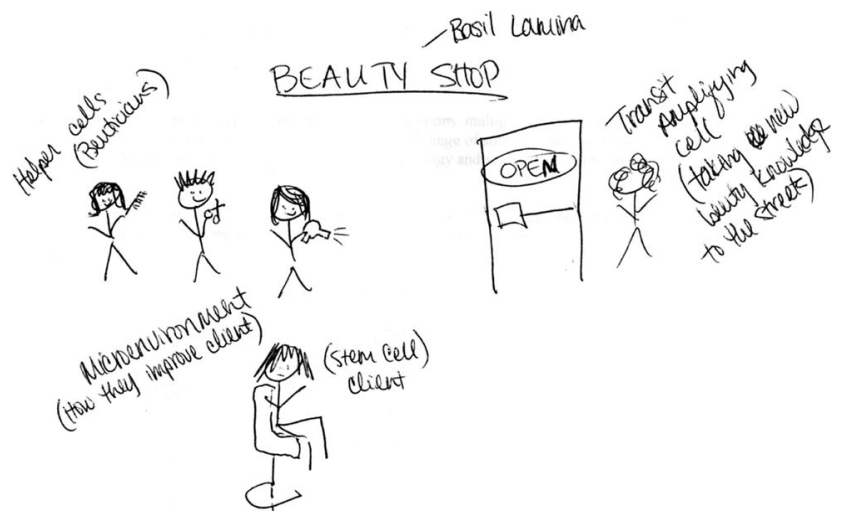

Figure 2. Student niche analogy. A student uses a beauty salon to describe a stem cell niche. The client represents the stem cell; the beauticians represent helper cells, who use components of the microenvironment (combs, hair dryer, etc.) to communicate with the stem cell. As a whole new look is created, this represents commitment to differentiation by the stem cell, after which the look is shared outside the niche in a process connoting transit-amplification.

monitor closely the framing of unfamiliar religions by students in their presentations to maintain a comfortable atmosphere for all in the room.

\section{Niche Analogies}

Students did not evaluate this strategy directly, so interpretation of its success in meeting Goal 2 was more difficult. There was one student journal entry with regard to the use of analogies:

\begin{abstract}
"The niche was a new concept for me. I've heard it used with animals based on their habitat but never in regard to cells. The five parts of the stem cell niche was easy to understand though with the analogy of the ship and dock and all of that. Also the group discussions of other analogies made the niche easier to comprehend and plus I was asked by a peer to describe what it meant and that made it even more easier to understand because I had to teach it to someone else in my own terms. I can see the benefit of knowing the microchemical signals in the niche based on research progress and how making a niche in lab artificially could lead to transplanting a niche from a lab to an organism and giving them a source of unlimited amounts of a specific type of adult stem cells."
\end{abstract}

An example of student work in Figure 2 shares a novel analogy for the stem cell niche. The student who created this analogy did very well on the scientific concept posttest. All students were able to produce an analogy on the examination. Based on analysis of the student-written analogies in the examination, the role of the transit-amplifying cells was the least understood.

\section{Persona Positions}

This strategy was used to address the first goal by creating an environment for the exploration of new beliefs and positions without the cost of sharing your own personal viewpoint. Overall, students felt this was one of the least effective strategies. Likely, additional time for group discussion in persona may have clarified the goals of this strategy.

\section{Nation-States}

This strategy was aimed at meeting Goal 3. The state of Missouri was in the midst of a public debate over stem cell legislation, and this appears to be reflected in the student evaluations. Students identified this strategy as somewhat effective in meeting our goal, but it must be pointed out that a large portion of the planned activities was omitted because of time constraints. We initially planned student presentations, but traded for an instructor-led lecture to address time issues. We did have time for a guest expert and group discussion. This strategy may have been more effective if students had researched legislation in different states and nations and given class presentations.

\section{Final Forum}

This activity was intended to help students meet all three goals. It was, in a sense, the final examination for the students. This discussion was the absolute highlight of the course. The inclusion of community members made the discussion authentic. The forum was extremely effective in meeting all three goals. Students shared their personal positions and listened to those of others. There were several small group discussions where students took it upon themselves to describe scientific concepts to the community volunteers and even to other students. Also, due to the breadth of our group's views, we were able to see the intersection of science and society.

Students later reported having continued conversations with members of their discussion group outside the class and greatly valued these interactions. Every one of the community volunteers later contacted us and expressed thanks for their inclusion in the activity.

\section{OVERALL COURSE EVALUATIONS}

As further evidence of positive student response to the course, we include a summary of our formal course evaluations completed by the students on the last day of the course. The course evaluation uses a 5-point scale for each item, with 5 being the most favorable response. The overall averages on the course evaluations are given below.

- Overall teaching effectiveness. . . . . . . . . . . 4.8

- Instructor as a discussion leader. . . . . . . . . . 5.0

- Atmosphere for student learning. . . . . . . . . . 5.0

- Encouragement given students to express themselves. . . 5.0

- Relevance and usefulness of course content. . . . . . . 4.9

Based on students' comments and course evaluations, we felt that the students' response to a socioscientific approach to learning about stem cells was overwhelming positive.

\section{CONCLUSION}

We found that using a socioscientific issues approach created a stimulating environment for learning about stem cell 
biology. Stem Cells and Society represents something new in our biology course offerings. Our students left the course asking for more courses designed with this approach. Based on our experience and our students' feedback and course evaluations, the inclusion of personal philosophy, religion, and law led to a greater understanding of the science of stem cell research. Additionally, we were able to include community outreach with our course work, which would satisfy the civic and cultural components of scientific literacy (NRC, 1996). If we are truly striving to meet the goal of "Science for all Americans" (AAAS, 1989), we might best succeed if we design courses that engage students in the context in which Americans find science-firmly embedded in religion, philosophy, politics, and law.

\section{REFERENCES}

American Association for the Advancement of Science (AAAS) (1989). Project 2061 Science for All Americans, ed. F. J. Rutherford and A. Ahlgren, Washington, DC: Oxford University Press.

AAAS (2003). Benchmarks for Science Literacy, Washington, DC: Oxford University Press.

Bivins, T. (2000). Ethical worksheet. http://jcomm.uoregon.edu/ $\sim$ tbivins/J397/Links/Worksheet.html (accessed 18 March 2008).

Difficult Dialogues, University of Missouri. (2007). http:// difficultdialogues.missouri.edu/ (accessed 18 March 2008).

Glynn, S. M., and Takahashi, T. (1998). Learning from analogyenhanced science text. J. Res. Sci. Teach. 35, 1129-1148.
Gross, P. R., Goodenough, U., Lerner, L. S., Haack, S., Schwartz, M., Schwartz, R., and Finn, C. E., Jr. (2005). The State of State Science Standards 2005, Washington, DC: Thomas B. Fordham Institute.

Kass, Leon (Ed.). (2004). Being Human: Core Readings in the Humanities, New York: W.W. Norton \& Co.

Martin, G. (1995). Borderline comics archive. www.nevtron.si/ borderline/old.html (accessed 18 March 2008).

Moore, J. (2006). Science literacy and science standards. J. Chem. Ed. 83, 343.

National Research Council (1996). National Science Education Standards, Washington, DC: National Academy Press.

PBS Home Video (2006). Test Tube Babies (DVD). Gazit, C. and Steinman, H.K. Producers and Directors. WGBH Educational Foundation.

Rotblat, J. (1999). A Hippocratic Oath for scientists. Science 286, 1475 .

Sadler, T. D., Chamber, F. W., and Zeidler, D. L. (2004). Student conceptualizations of the nature of science in response to a socioscientific issue. Int. J. Sci. Educ. 26, 387-409.

Scott, C. (2006). Stem Cells Now, New York: Plume, a division of Penguin Group.

Secretary of State Robin Carnahan, Missouri (SOS-MO). (2005). 2006 Ballot Measure Constitutional Amendment 2 Stem Cell Initiative (2005). www.sos.mo.gov/elections/2006petitions/ppStemCell.asp (accessed 18 March 2008).

Zeidler, D. L., Sadler, T. D., Simmons, M. L., and Howes, E. V. (2005). Beyond STS: a research-based framework for socioscientific issues education. Sci. Educ. 89, 357-377. 